\title{
FACTOR ANALYSIS OF PRICES AND AGRICULTURAL PRODUCTION IN THE EUROPEAN UNION
}

\author{
Goran Popović ${ }^{1}$, Ognjen Erić ${ }^{1}$, Jelena Bjelić
}

date of paper receipt:

11.02.2020.

Original Article date of sending to review:

13.02.2020.

doi: 10.2478/eoik-2020-0001 date of review receipt:

24.02.2020.

UDK:

338:347.7:351.823.1(4-672EU)

\footnotetext{
${ }^{1}$ University of Banja Luka, Faculty of Economics, Bosnia and Herzegovina

${ }^{2}$ Indirect Taxation Authority, Bosnia and Herzegovina
}

\begin{abstract}
Common agricultural policy (CAP) is a factor of development and cohesion of the European Union (EU) agriculture. The fundamentals of CAP were defined in the 1950s, when the Union was formed. Since then, CAP has been reforming and adapting to new circumstances. Treaty on the Functioning of the European Union defines the goals of CAP: stable (acceptable) prices of agricultural products, growth, productivity and technological progress in agriculture, growth in farmers' income and supplying the common market. Factor analysis of the prices and production goals of CAP directly or indirectly involves the following variables: prices of agricultural and industrial products, indices of the prices of cereals, meat and milk, indices of the prices of agricultural products in France and Great Britain, agricultural GDP and EU GDP. The analysis results come down to 2 factors. The first "internal factor" is a set of indicators homogenous in terms of greater impact of CAP on their trends (the prices of agricultural products in France, income from agriculture, the prices of agricultural products in EU and Great Britain and the milk price index). The second - "external factor" is made of general and global indicators (cereals prices, EU GDP and prices in industry). Factor analysis has confirmed high correlation of goals: production growth, productivity and technological progress in agriculture as well as "reasonable" prices in agriculture. The analysis shows high correlation between agricultural and industrial products, indices of the prices of cereals, meat and milk, indices of the prices of agricultural products in France and Great Britain, agriculture GDP and EU GDP (classified into internal and external factors). In general, the results of the factor analysis justify the existence of CAP, while the EU budget support brings wider social benefits.
\end{abstract}

\section{Keywords:}

European Union, Common Agricultural Policy, agricultural products, agricultural prices, factor analysis

JEL: Q18, O52, C38 


\section{INTRODUCTION}

\section{GENERAL APPROACH}

The foundations of the Common Agricultural Policy were set by the European Community which later grew into the EU. CAP has been continuously reformed, whereby the initial goals have been adapted to new circumstances. Treaty on the Functioning of the European Union, in particular Articles 38-42, define the scope, goals and the position of CAP in the EU. Article 38 pertains to the following goals: productivity growth and technological progress in agriculture, increase in farmers' life standard, stabilisation of the common market and supply of the whole territory of the Community, as well as one of the key goals - supplying consumers under "reasonable" prices.

\section{LITERATURE REVIEW}

Ackrill (2008 a) provides a synthesis of CAP evolution, while Moyer and Josling (1990), Kay (1998), Swinnen (2008) and Swinbank and Daugbjerg (2006) analyse key reforms of CAP that have unfolded in decades. Most authors find that the reforms are implemented in accordance with the given internal and global circumstances. Regardless of frequent counterpositions, the reforms have preserved the continuity of this common policy. Further, Baldwin and Wyplosz (2006) observe CAP in the context of price and other support. Support instruments are also analysed by Grant (2010), while the global aspects of CAP are analysed by Garzon (2007). Besides that, Ackrill does the analysis of CAP in the context of EU budget support.

There arises the question: Does the EU budget support have an impact on the trends of the fundamental economic indicators in the EU agriculture (and if yes, then how?), that is, to what extent is the support to the EU agriculture justified? Therefore, the subject of research encapsulated in this paper is the EU Common Agricultural Policy, and the paper directly or indirectly involves the majority of the goals through the set hypotheses.

For example, the production and prices of agricultural products and food are key economic indicators which explain the character of CAP in the context of achieving the set goals. There are numerous researches in this field. For example, according to Robert Ackrill, the connection between the budget and prices is a reality because "instruments of price support had a major impact on the EU budget". Ackrill (2008 b) finds that "the EC system of price support would also involve variable import levies rather than fixed tariffs". Prices as the key instrument of CAP are also analysed by Popović (2016).

CAP is a current topic in the countries of the Central and Eastern Europe too, as well as in the candidate countries for accessing the EU (Spasojević et al, 2018). Gorton et al. (2009) analyse the regional aspects of CAP, whereas Tangermann and Banse (2000) deal with the CAP expansion on a wider territory of Europe. Lovec and Erjavec (2012) analyse the "Big Bang" phenomenon in the development and expansion of the EU CAP.

This research applies factor analysis. For these needs, a larger number of variables is used to assess the CAP success. Statistical data involve the period from 2007 to 2016 . They have been taken from the EUROSTAT base. The period is relevant as it not only involves the pre-crisis year, but also the crisis period $(2008,2009)$, as well as the period of economic stabilisation until 2016. 


\section{METHODOLOGY}

Indicators from the agriculture sector, variables from other sectors (industry) and indicators relevant for the whole Union will be used in statistical and econometric analysis.

It is about the following variables: (a) the prices of agricultural products are the main goal of CAP, (b) index of the prices of industrial products (industrial prices have an impact on inputs in agriculture), (c) indices of the prices of cereals, meat and milk as the key nutritional products, (d) indices of the prices of agricultural products in France and Great Britain, (e) agriculture GDP that expresses the value of agricultural production and is connected to productivity growth, as well as (f) total EU GDP as the representation of the size of the European market.

The multivariate factor analysis used is a set of statistical-mathematical procedures which can determine the connection between the observed phenomena (variables), whereby growth in the number of variables brings about an increase in the need for knowing their structure and interrelations. Analysis is the principal methodological framework of econometric modelling.

Models in the narrow sense mostly belong to the set of multivariate models although they can include univariate autoregressive models as well. This paper makes use of the PCA technique based on variances with a reduction in the problem dimension and keeping the maximal variability possible. The initial variables are transformed into linear combinations of the original variables in order to include the greatest part of the variance of the original variable set possible.

Factor analysis is implemented in four steps: an estimation of justification of factor analysis, separation, factor rotation and calculation of factor scores. In principle, this analysis is the technique of reducing the amount of data by reducing the original variable set to a set of small number of factors, whereby another, not directly visible dimension is identified. Hence the choice of this method is optimal for the assessment of the complex EU CAP.

Reduction in the number of variables facilitates the interpretation of the solution. Variants (factors) are formed in order to maximise the explanation of the whole set of variables, not to predict the dependent variable (or variables). Stock and Watson $(1998,2002)$ researched factor analysis and estimates of macroeconomic variables. Efficiency of dynamic factor models has been improved by means of software solutions in the form of SPSS and further progress which has been confirmed by Kapetanios and Marcellino (2004), while Forni et al. (2015) base their estimates on spectral analysis.

In its form, factor analysis model is represent as follows:

$X_{i}=A_{i 1} F_{1}+A_{i 2} F_{2}+A_{i 3} F_{3}+\ldots+A_{i m} F_{m}+V_{i} U_{i}$

where:

$\mathrm{X}_{\mathrm{i}}$ - i-standardized variable,

$A_{i j}$ - standardized quotient of multiple regression of the variable " $i$ " to the common factor “ $j$ ",

$F_{j}$ - common factor “ $j$ ",

$V_{i}$ - standardized regression quotient of the variable "i" to "unique" factor " $i$ ",

$U_{i}$ - "unique" factor for the variable "i",

$\mathrm{m}$ - the number of common factors. 
Each variable is a linear combination of separated factors $\left(\mathrm{F}_{\mathrm{j}}\right)$ and part of the "unique" factor for every variable $\left(U_{i}\right)$.

Common factors can be expressed as linear combinations of the observed variables, that is:

$F_{i}=W_{i 1} X_{1}+W_{i 2} X_{2}+W_{i 3} X_{3}+\ldots+W_{i k} X_{k}$

where:

$F_{i}$ - estimation of i-factor,

$\mathrm{W}_{\mathrm{i}}$ - weight or factor "score" quotient,

$\mathrm{k}$ - the number of variables.

Econometric models in the narrow sense mostly belong to the set of multivariate models. Kollo and Rosen (2005) observe econometric models as univariate and multivariate. Hwang and Yoon (2006) see them as ideal for the integration of intuitive and statistical estimation models.

Most importantly, these types of analyses are used for researching the question of whether independent variables explain a significant part of the variability of dependent variables (whether they exist and what the connection intensity is), that is, to determine the part of variability of the dependent variable which has been explained in terms of one or more independent variables. The beginning of the multivariate factor analysis process is followed by statistical models that precede the factor analysis.

As has been said, the starting point in this research is the claim that the goals of the EU CAP offer long-term production and price stability of agricultural products and food. The economic justification of the CAP support from the EU budget and other funds is proved thereby.

\section{THE EU CAP KEY INDICATORS TREND: FACTOR ANALYSIS}

All variables are being analysed, without determining dependent and independent variable(s). The variables are represented in the following table:

Table 1. Main components - variables

\begin{tabular}{|c|c|c|c|c|c|c|c|c|c|}
\hline Years & ${ }^{\star} \mathbf{X} \mathbf{1}$ & ${ }^{\star} \mathbf{X} \mathbf{2}$ & ${ }^{\star} \mathbf{X} \mathbf{3}$ & ${ }^{\star} \mathbf{X} \mathbf{4}$ & ${ }^{\star} \mathbf{X} \mathbf{5}$ & ${ }^{\star} \mathbf{X} \mathbf{6}$ & ${ }^{\star} \mathbf{X} \mathbf{7}$ & ${ }^{*} \mathbf{X 8}$ & ${ }^{\star} \mathbf{X} \mathbf{9}$ \\
\hline 2007 & 92 & 113 & 112 & 100 & 110 & 121 & 97 & 12.994 & 50 \\
\hline 2008 & 94 & 120 & 110 & 102 & 106 & 120,3 & 124 & 13.068 & 53 \\
\hline 2009 & 93 & 97 & 76 & 102 & 75 & 78,9 & 90 & 12.312 & 36 \\
\hline 2010 & 96 & 100 & 100 & 100 & 100 & 100 & 100 & 12.829 & 45 \\
\hline 2011 & 99 & 111 & 135 & 107 & 123 & 135 & 145 & 13.202 & 56 \\
\hline 2012 & 102 & 107 & 146 & 109 & 135 & 143 & 150 & 13.463 & 60 \\
\hline 2013 & 102 & 120 & 131 & 114 & 117 & 130 & 153 & 13.577 & 56 \\
\hline 2014 & 102 & 122 & 114 & 115 & 103 & 114 & 120 & 14.044 & 53 \\
\hline 2015 & 100 & 102 & 111 & 115 & 102 & 107 & 103 & 14.797 & 50 \\
\hline 2016 & 99 & 96 & 102 & 116 & 102 & 97 & 101 & 14.904 & 44 \\
\hline
\end{tabular}

${ }^{\star} \mathrm{X} 1$ - Industry price index EU 28, X2 - Milk price index EU 28, X3 - Agricultural product price index EU 28, X4 - Cereals price index EU 28, X5-Agricultural GDP index EU 28, X6- Agricultural product price index - France, X7- Agricultural product price index - Great Britain, X8- EU GDP Billion Euros, X9-Total agricultural production EU 28 Billion Euros

Source: Eurostat, 2018.

For the conduct of Factor analysis, the software SPSS IBM, version 23 and the method of Main 
Components Analysis are used. Analysis of descriptive measures shows that the EU GDP has the highest average value, followed by Total agricultural income, then the indexes of Agricultural product price in Great Britain (118) and France (115) etc. Similarly, the first two variables (EU GDP and Agricultural income) have the highest standard deviation, followed by Great Britain (24), Agricultural product price index (20), then Agricultural product price index in France.

The correlation matrix shows the values of Pearson's quotient of the correlation between all the variables (Table 2).

Table 2. Correlation Matrixa

\begin{tabular}{|c|c|c|c|c|c|c|c|c|c|c|}
\hline \multirow{10}{*}{ 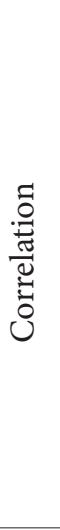 } & & Icind & Icmilch & $\mathrm{IcPP}$ & Iccereals & GDPpp & IcppFranc & IcppGBrit & GDPEU & UppEU \\
\hline & Icind & 1,000 & & & & & & & & \\
\hline & Icmilch &, 235 & 1,000 & & & & & & & \\
\hline & IcPP & ,633 &, 517 & 1,000 & & & & & & \\
\hline & Iccereals & 857 & ,085 & ,335 & 1,000 & & & & & \\
\hline & GDPpp &, 518 & ,432 & ,974 & ,233 & 1,000 & & & & \\
\hline & IcppFranc & ,447 & ,636 & 967 & , 145 & ,956 & 1,000 & & & \\
\hline & IcppGBrit & ,669 &, 594 & ,889 & ,327 & 815 &, 860 & 1,000 & & \\
\hline & GDPEU & ,603 &,- 089 & ,201 & ,864 & , 180 & ,039 &, 029 & 1,000 & \\
\hline & UppEU &, 578 &, 681 & ,961 & ,288 & 920 & ,968 & ,857 &, 182 & 1,000 \\
\hline \multirow{9}{*}{ 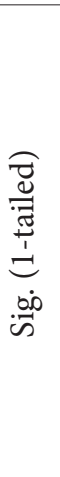 } & Icind & & & & & & & & & \\
\hline & Icmilch & ,257 & & & & & & & & \\
\hline & IcPP & ,025 &, 063 & & & & & & & \\
\hline & Iccereals & ,001 & ,407 & , 172 & & & & & & \\
\hline & GDPpp &, 063 & , 106 & ,000 & ,259 & & & & & \\
\hline & IcppFranc & ,098 &, 024 & ,000 &, 345 & ,000 & & & & \\
\hline & IcppGBrit & ,017 & ,035 & ,000 &, 178 & ,002 &, 001 & & & \\
\hline & GDPEU & ,033 & ,404 & ,289 & ,001 & ,309 & , 457 &, 469 & & \\
\hline & UppEU & ,040 & ,015 & ,000 & ,210 & ,000 & ,000 & ,001 &, 307 & \\
\hline
\end{tabular}

a. Determinant $=3,109 \mathrm{E}-11$

Source: Author's calculations

It can be seen that the Agricultural GDP is in the strongest correlation with IcPP in the EU (0.947), that is, the value of agricultural production has the greatest correlation with the price trend in agriculture on the EU level. The correlation between the Agricultural product price index in France and the EU IcPP is 0,967 . The correlation between the Agricultural product price index in France and the Agricultural GDP is 0,956 etc.

Correlation quotients confirm the hypotheses that the Agricultural GDP is affected by the prices of agricultural products and food, that is, price growth influences higher agrarian revenue.

In the second case, the quotient of correlation shows the great influence of the prices of French agriculture over total prices in the EU, which is characteristic for a country which is the agrarian leader in the Union.

The third correlation confirms a strong bond between the Agricultural product price index in France and the Agricultural GDP in the whole EU. Therefore, the total agricultural income of the EU depends on the prices of agricultural products in France.

Tests to justify the application of factor analysis are Bartlett's test and KMO statistics. The first test is based on Chi-square statistics. For Sig. $=0,000$ the null hypothesis is rejected. For KMO statistics the rule applies that if the value is higher (than 0,5 ), the use of factor analysis is recommended. The value of KMO statistics is 0.428 (limit of acceptability). In the common variability of all variables 
there are no major discrepancies.

Total Variance Explained analysis shows that the percentage of the explained variable for two factors is $87 \%$ (table 3 ).

Table 3. Total Variance Explained (Extraction Method: Principal Component Analysis-PCA)

\begin{tabular}{|c|c|c|c|c|c|c|c|c|c|}
\hline $\begin{array}{c}\text { 宗 } \\
\text { Uे }\end{array}$ & \multicolumn{3}{|c|}{ Initial Eigenvalues } & \multicolumn{3}{c|}{ Extraction SS Loadings } & \multicolumn{3}{c|}{ Rotation SS Loadings } \\
\hline & Total & $\begin{array}{c}\% \text { of } \\
\text { Variance }\end{array}$ & $\begin{array}{c}\text { Cumulat. } \\
\%\end{array}$ & Total & $\begin{array}{c}\% \text { of } \\
\text { Variance }\end{array}$ & $\begin{array}{c}\text { Cumulat. } \\
\%\end{array}$ & Total & $\begin{array}{c}\% \text { of } \\
\text { Variance }\end{array}$ & $\begin{array}{c}\text { Cumulat. } \\
\%\end{array}$ \\
\hline 1 & 5,659 & 62,882 & 62,882 & 5,659 & 62,882 & 62,882 & 5,162 & 57,360 & 57,360 \\
\hline 2 & 2,166 & 24,068 & 86,950 & 2,166 & 24,068 & 86,950 & 2,663 & 29,590 & 86,950 \\
\hline 3 &, 645 & 7,164 & 94,113 & & & & & & \\
\hline 4 &, 420 & 4,666 & 98,780 & & & & & & \\
\hline 5 &, 062 &, 688 & 99,467 & & & & & & \\
\hline 6 &, 028 &, 311 & 99,778 & & & & & & \\
\hline 7 &, 018 &, 199 & 99,977 & & & & & & \\
\hline 8 &, 002 &, 022 & 99,998 & & & & & & \\
\hline 9 &, 000 &, 002 & 100,000 & & & & & & \\
\hline
\end{tabular}

Source: Author's calculations

It is noticeable that after the second factor the characteristic values gradually decrease and therefore two factors are selected.

Table 4. Original (initial) factor weights

\begin{tabular}{|c|c|c|}
\hline \multirow{2}{*}{} & \multicolumn{2}{|c|}{ Component } \\
\cline { 2 - 3 } & 1 & 2 \\
\hline IcPP &, 974 & \\
\hline UppEU &, 966 & \\
\hline IcppFranc &, 932 &,- 322 \\
\hline GDPpp &, 919 & \\
\hline IcppGBrit &, 915 & \\
\hline Icind &, 731 &, 580 \\
\hline Icmilch &, 618 &,- 354 \\
\hline GDPEU & &, 877 \\
\hline Iccereals &, 470 &, 859 \\
\hline Source: Auth
\end{tabular}

Source: Author's calculations

For the selected factor weights greater than 0,3 some fields are blank. Based on the values shown, it is difficult to single out only some of the variables which best explain the individual factors. For these reasons, the factor rotation method is applied. 
Table 5. Factor rotation - Rotated Component Matrixa

\begin{tabular}{|c|c|c|}
\hline \multirow{2}{*}{} & \multicolumn{2}{|c|}{ Component } \\
\cline { 2 - 3 } & 1 & 2 \\
\hline IcppFrancuska &, 985 & \\
\hline UppEU &, 960 & \\
\hline IcPP &, 944 & \\
\hline GDPpp &, 915 & \\
\hline IcppVelikaBrit &, 905 & \\
\hline Icmlijeka &, 706 & \\
\hline Icžitarica & &, 973 \\
\hline GDPEU & &, 925 \\
\hline Icind &, 459 &, 813 \\
\hline
\end{tabular}

Extraction Method: Principal Component Analysis. Rotation Method: Varimax with Kaiser Normalization. a. Rotation converged in 3 iterations.

Source: Author's calculations

After the rotation a factor matrix is obtained. For every factor, high values of factor weights associated with a small number of variables are allocated. Variables: Agricultural product price index in France, Total agricultural production of the EU, Agricultural product price index, Agricultural GDP, Agricultural product price index in Great Britain, Milk price index have high weight quotients with the first factor. Similarly, variables: Cereals price index, EU GDP, Industry price index, are distinguished by high weights with the other factor.

The squares of correlation quotients are the proportions of variance of certain variables attributed to the influence of a given factor. For the first factor we have: $0,982=0,9604=96,04 \%, 0,9602=$ $92,16 \%, 0,9442=89,11 \%$, etc. For the second factor we have: $0,9732=94,67 \%$, etc.

Conclusion: the first factor explains $96,04 \%$ variance of the Agricultural product price index in France variable, $92,16 \%$ variance of the Total agricultural production in the EU variable, $89,11 \%$ variance of the Agricultural product price index variable, 83,72\% variance of the Agricultural GDP variable, $81,90 \%$ variance of the Agricultural product price index in Great Britain variable, 49,84\% variance of the Milk price index variable.

The second factor explains: 94,67 variance of Cereals price index variable, 85,56\% variance of EU GDP variable, $66,10 \%$ Industry price index.

Based on the results of the analysis, the following interpretation is possible: the first factor relates to internal influences, that is, internal factors, because Agricultural product price index in France, Total agricultural income, Agricultural product price index, Agricultural GDP, Agricultural product price index in Great Britain and Milk price index are under great influence and jurisdiction of CAP. That is, the CAP measures can influence the value of the aforementioned indicators.

The second group, that is, the second factor are the external factors which include: EU cereals price index (affected by world prices), then EU GDP (aggregately reflects the size of the common market of the EU as a global economic actor), and the Index of industry prices which influence the inputs in agriculture. Apart from partially influencing the production of cereals, EU CAP has no significant influence on the majority of the indicators from external (second) factors.

Component Score Coefficient Matrix analysis shows the coefficients (scores) by which the original variables are multiplied. Both the first and the second factors have high values of coefficients related to the mentioned variables.

Therefore, by applying factor analysis procedure, a greater number of original variables is reduced to 2 factors, which maximally "summarise" characteristic information about the observed variables. 


\section{DISCUSSION}

Common Agricultural Policy is the fundamental common policy of the EU. The European Union has set explicit CAP goals, where stable and "acceptable" prices, the growth of production and productivity in agriculture etc. are emphasised.

The Union applies various measures and uses a number of instruments to support agriculture and food production. The measures are implemented by the EU institutions as well as national governments but under communitarian jurisdiction.

A correlation between key economic variables and CAP goals has been demonstrated as an objective within the research subject - justification of support from the EU budget for the needs of CAP. Factor analysis starts from the variables: agricultural product prices, industrial product price index, indexes of cereals, meat and milk prices, agricultural product price indexes in France and Great Britain, agricultural GDP and EU GDP. Results of factor analysis: Agricultural GDP is in the strongest correlation with Agricultural production price $(0,974)$ etc. Agricultural product prices $(0,989)$ and Agriculture GDP $(0,982)$ have the greatest variability. KMO statistics test is 0,459 and is on the verge of acceptability of factor analysis use.

According to Total Variance Explained, two factors stand out and the percentage of the explained variance is high and is approximately $80 \%(79,2 \%)$.

As it was impossible to single out the variables which best explain individual factors, factor "rotation" was performed. Rotated Component Matrix shows that Growth $(0,966)$ has a high weight quotient with the first factor. Variables Agricultural production prices $(0,981)$ and Agriculture GDP $(0,0979)$ have high weight quotients with the second factor.

Initial variables are "reduced" to 2 factors (first and second).

The first factor or the so-called internal factor, is a set of indicators which are homogenous in terms of the possibility of direct impact of CAP measures on their trends (agricultural product prices in France, GDP, that is, the agricultural income, agricultural product prices in the EU, agricultural product prices in Great Britain and Milk price index).

The second factor is the so-called external factor consisting of other general and global indicators (cereals prices, EU GDP and prices in industry).

\section{CONCLUSION}

Factor analysis confirmed the theory that the goals of CAP, such as the growth of production, productivity and technological growth in agriculture, as well as the so-called reasonable prices in agriculture, are generally realised. Hence the support for agriculture, to which most of the EU budget is allocated, is economically justified.

Thus, according to factor analysis results, CAP goals and support are economically justified, as evidenced by high correlations between the variables: agricultural and industrial product prices, indexes of cereals, meat and milk prices, agricultural product price indexes in France and Great Britain, agricultural GDP and EU GDP (classified into 2 groups - internal and external factor).

That is, factor analysis results justify high financial allocations from the EU budget. The realisation of CAP goals does not generate only economic benefits. Along with them, the agricultural condition reflects on the social sphere and other areas of social cohesion. 


\section{REFERENCES}

Ackrill, R. (2008 a). EU Agricultural Law. European Review of Agricultural Economics, 35(4), 591-593. doi:10.1093/erae/jbn035

Ackrill, Robert. (2008 b). The CAP and its Reform-Half a Century of Change? Die GAP und ihre Reform-50 Jahre im Wandel? La PAC et sa réforme-Un demi-siècle de changement? Eurochoices, 7(2), 13-21. doi:10.1111/j.1746-692x.2008.00094.x

Adrian, K., \& Ackrill, R. (2011). Problems of composition, temporality and change in tracing the Common Agricultural Policy through time. JEIH Journal of European Integration History, 16(2), 123-143. doi:10.5771/0947-9511-2010-2-123

Baldwin, R., \& Wyplosz, C. (2009). European Economic Integration.

Forni, M., Hallin, M., Lippi, M., \& Zaffaroni, P. (2015). Dynamic factor models with infinitedimensional factor spaces: One-sided representations. Journal of Econometrics, 185(2), 359-371. doi:10.1016/j.jeconom.2013.10.017.

Eurostat (2018). Agricultural price, price indices and production. Retrieved from https://ec.europa. eu/eurostat/data/database

Garzon, I. (2007). A Changing Global Context in Agricultural Policy. Notre Europe.

Gorton, M., Hubbard, C., \& Hubbard, L. (2009). The folly of European Union policy transfer: Why the Common Agricultural Policy (CAP) does not fit Central and Eastern Europe. Regional Studies, 43(10), 1305-1317. doi:10.1080/00343400802508802

Grant, W. (2010). Policy Instruments in the Common Agricultural Policy. West European Politics, 33(1), 22-38. doi:10.1080/01402380903354049

Kay, A. (1998). The reform of the Common Agricultural Policy: The case of the MacSharry reforms. CAB INTERNATIONAL.

Kollo, T., \& von Rosen, D. (2005). Advanced multivariate statistics with matrices (Vol. 579). Springer Science \& Business Media. doi:10.1007/1-4020-3419-9

Lovec, M., \& Erjavec, E. (2012). “ Big bang” enlargement and Common agricultural policy reform. Društvena Istraživanja: Časopis Za Opća Društvena Pitanja, 21(1 (115)), 219-238. doi:10.5559/di.21.1.12

Moyer, H. W., \& Josling, T. E. (1990). Agricultural policy reform: Politics and process in the EC and USA. Harvester Wheatsheaf. ISBN 0-7450-0655-8

Popović, G. (2016). Economy of European Union (Ekonomija Evropske unije). Istočno Novo Sarajevo: Zavod za udžbenike i nastavna sredstva.

Spasojević, B., Djukic, A., \& Erić, O. (2018). Price stability of agricultural products in the European Union. Economics of Agriculture, 65(4), 1585-1598. doi:10.5937/ekopolj1804585s.

Stock, J. H., \& Watson, M. W. (1998). Median unbiased estimation of coefficient variance in a time-varying parameter model. Journal of the American Statistical Association, 93(441), 349-358. doi:10.1080/01621459.1998.10474116

Stock, J. H., \& Watson, M. W. (2002). Macroeconomic forecasting using diffusion indexes. Journal of Business \& Economic Statistics, 20(2), 147-162. doi:10.1198/073500102317351921

Swinbank, A., \& Daugbjerg, C. (2006). The 2003 CAP reform: Accommodating WTO pressures. Comparative European Politics, 4(1), 47-64. doi:10.1057/palgrave.cep.6110069

Swinnen, J. F. (2008). The perfect storm: The political economy of the Fischler reforms of the common agricultural policy. CEPS. doi:10.2139/ssrn.1360735

Tangermann, S., \& Banse, M. (2000). Central and Eastern European agriculture in an expanding European Union. CABI. doi:10.1079/9780851994253.0000 